\title{
Lead Poisoning Caused by Traditional Chinese Medicine: A Case Report and Literature Review
}

\author{
Guangmin Tang, ${ }^{1, *}$ Xiang Tu, ${ }^{2, *}$ and Ping Feng ${ }^{1}$ \\ ${ }^{1}$ Center of Infectious Diseases, West China Hospital, Sichuan University, Chengdu, Sichuan Province, China \\ ${ }^{2}$ West China Medical School, Sichuan University, Chengdu, Sichuan Province, China
}

Traditional Chinese herbal medicine is widely used for primary health care worldwide as it mostly consists of herbs or herbal extracts known to be safe. However, owing to the intentional or unintentional addition to herbs of lead-containing bases or pastes, lead poisoning from traditional Chinese medicine (TCM) remains a serious issue. We report here a case of lead poisoning caused by long-term use of homemade TCM. A 66-year-old man was admitted for periumbilical pain and constipation. A detailed medication history revealed that the patient had been using homemade TCM for the past 8 months. Screening for heavy metals showed that the patient had a blood lead level of $657 \mu \mathrm{g} / \mathrm{L}$ and his wife, who was asymptomatic, had a blood lead level of $488 \mu \mathrm{g} / \mathrm{L}$. Chemical analysis confirmed a lead concentration of more than 4,000 mg/ $\mathrm{kg}$ in the TCM. Both individuals were advised to discontinue the medications and chelation treatment was immediately initiated for the husband. The patient's periumbilical pain was noticeably relieved after treatment, and blood lead levels returned to normal after three treatment rounds. We also review here the literature to summarize the usual reasons for taking TCM and common features of lead poisoning. Our findings suggest that potential exposure to lead from TCM treatment must be considered when diagnosing unexplained cases of abdominal colic in China. The Chinese health authority should speed up legislation to improve the regulatory framework of TCM, especially regarding small private clinics.

Keywords: case report; drug; lead colic; lead poisoning; traditional Chinese medicine

Tohoku J. Exp. Med., 2017 October, 243 (2), 127-131. C 2017 Tohoku University Medical Press

\section{Introduction}

Traditional Chinese herbal medicine is widely used for primary health care worldwide (Auyeung et al. 2002). The herbs and herbal extracts used in traditional Chinese medicine (TCM) are assumed to be mostly safe; however, their potential toxicity and adverse side effects should not be ignored (Shaw 2010). The most common TCM toxic reactions arise from the mislabeling of plant material or from botanical misidentification (which occurs because some plant descriptions have changed over time) (Efferth and Kaina 2011). In addition, the contamination of herbal ingredients with fungal toxins, micro-organisms, pesticides, and heavy metals may raise safety issues. The production and sale of TCM in China requires certification passports (Good Agricultural Practice; Good Supply Practice) and the official system prohibits individual practitioners from making and selling uncertified TCM. However, owing to the large number of uncertified private TCM clinics and nonprofessional practitioners in small communities (especially in rural areas) and a lack of public awareness about sourc- ing good quality herbal medicine, TCM toxicity (particularly from heavy metals) remains a major issue. In recent decades, there have been frequent reports of lead exposure from the storage of TCM in lead-containing bases or the addition of lead pastes to TCM. Owing to the atypical manifestations of lead poisoning and the low awareness of possible TCM-related lead exposure, the diagnosis of TCMrelated lead poisoning is challenging and diagnoses are often delayed (Gupta et al. 2011; Lin et al. 2012). We report here a case of early detection of lead poisoning caused by long-term use of homemade TCM and estimate the prevalence of TCM-related lead poisoning in the community.

\section{Case Report}

A 66-year-old man was admitted to the Center of Infectious Diseases at West China Hospital for periumbilical pain after meals. This had occurred for 1 month and had been accompanied by constipation for the past 10 days. On physical examination, the patient's vital signs, neurological examination, and chest examination were normal.

Received August 8, 2017; revised and accepted October 12, 2017 . Published online October 27, 2017; doi: 10.1620/tjem.243.127.

*These authors contributed equally to this work and should share first author status. China.

Correspondence: Ping Feng, Center of Infectious Diseases, West China Hospital, Guoxuexiang 37, Chengdu, Sichuan Province 610041,

e-mail: hxfengping@126.com 
The abdominal examination revealed hypoactive bowel sounds and mild abdominal tenderness that was relieved by slight malaxation. Laboratory tests revealed moderate normocytic anemia (hemoglobin concentration $75 \mathrm{~g} / \mathrm{L}$ ) with raised reticulocyte of $10.2 \%$. Serum iron, folate, and vitamin B12 levels were normal. A negative Coomb's test showed no evidence of hemolysis and haptoglobin was normal. A liver function test showed hyperbilirubinemia (total bilirubin $56.5 \mu \mathrm{mol} / \mathrm{L}$, direct bilirubin $24.9 \mu \mathrm{mol} / \mathrm{L}$ ) and a slightly increased level of liver transaminases (aspartateaminotransferase $54 \mathrm{IU} / \mathrm{L}$ ). Tests for hepatitis B and autoimmune diseases were negative. Abdominal ultrasound and computed tomography (CT) scan located a liver cyst that was approximately $1.3 \mathrm{~cm} \times 1.0 \mathrm{~cm}$. Gastroscopy showed a fundic gland polyp and chronic non-atrophic gastritis; a colonoscopy revealed nothing except internal hemorrhoids. After supportive therapy for about 5 days, the patient's symptoms had not remitted. We then revisited the patient's detailed medication history and found that he had been taking homemade TCM for atherosclerosis prevention obtained from a Chinese medicine practitioner. The patient had been taking an approximate dose of $15 \mathrm{~g}$ /day for 8 months. We subsequently screened for heavy metals, including mercury, arsenic, and lead. The results revealed an elevated blood lead level of $657 \mu \mathrm{g} / \mathrm{L}$ (normal $<400 \mu \mathrm{g} / \mathrm{L}$ ) and a urine lead level of $127.5 \mu \mathrm{g} / \mathrm{L}$ (normal $<70.38 \mu \mathrm{g} / \mathrm{L}$ ). We also tested his wife, who had taken the same medicine for the past few months but was asymptomatic, and discovered a blood lead level of $488 \mu \mathrm{g} / \mathrm{L}$ and a urine lead level of $97.1 \mu \mathrm{g} / \mathrm{L}$. Both individuals were advised to discontinue the medications and chelation treatment was immediately initiated for the husband. His periumbilical pain was noticeably relieved after treatment and the blood lead level returned to normal after three treatment rounds. As she was asymptomatic and showed only a slightly elevated blood lead level, his wife did not receive chelation therapy.

To confirm the typical clinical manifestations of lead poisoning, we performed a bone marrow needle biopsy but found only erythroid hyperplasia in the bone marrow. The blood smear revealed teardrop erythrocytes with no specificity. Electromyography showed distal multiple peripheral nerve damage in accordance with typical neurological damage owing to lead poisoning.

\section{Lead Source Inquiry}

To test whether the lead came from the homemade TCM, we visited TCM practitioners in the local community and obtained medicinal samples (Fig. 1). Chemical analysis of the medicine (based on the National Food Safety Standard's Determination of Lead in Foods, GB5009.122010) revealed an elevated lead content of more than 4,000 $\mathrm{mg} / \mathrm{kg}$. As this local TCM practitioner had treated a large number of patients, we presume that more people in the community have been affected by taking medicines with high lead concentrations. Unfortunately, the practitioner refused to comment or cooperate in the follow-up investiga-

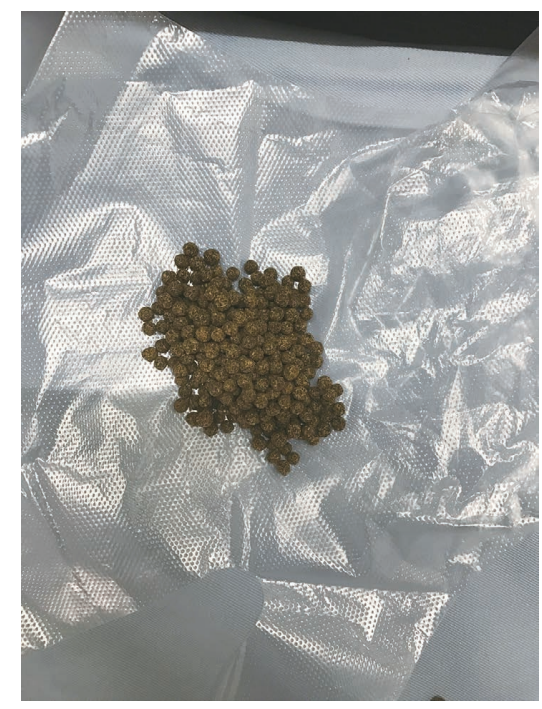

Fig. 1. Samples of traditional Chinese medicine (TCM) obtained from TCM practitioners in the local community. The patient took a daily dose of $15 \mathrm{~g}$ (about 400 pills) per day (as indicated) for 8 months. The wrapping paper showed in the picture is a plastic bag used for packaging the pills.

tions.

\section{Literature Review}

We searched PubMed and reviewed the literature on lead poisoning caused by TCM using the keywords "lead poisoning" and "medicine, Chinese traditional." We identified 10 relevant case reports (Lightfoote et al. 1977; Markowitz et al. 1994; Auyeung et al. 2002; Woolf et al. 2008; Prakash et al. 2009; Lin et al. 2012; Wu et al. 2013; Deng et al. 2016; Ying et al. 2016; Tsai et al. 2017) from 1977 to 2017 (Table 1). To summarize these, the reasons for taking TCM varied across individuals. The main symptoms of lead poisoning caused by TCM use included periumbilical abdominal pain (lead colic), constipation, and other nonspecific symptoms such as muscle pain, fatigue, and irritability. Laboratory tests often revealed anemia with basophilic stippling of red cells on peripheral blood smear, slightly abnormal liver function (mainly with increasing level of indirect bilirubin), neuropathy with extensor weakness, and a "lead line" which showed as a bluish pigmentation over the gum or joint. However, ultrasound, CT, and endoscopy of the digestive system generally showed no specific organic lesions. A detailed review of the patient history may reveal a long TCM medication history associated with excessive lead exposure.

\section{Discussion}

Based on the false assumption that herbal medicine has no side effects (as most ingredients are herbal extracts), it has been widely used worldwide, especially in Chinese and Indian communities. However, lead poisoning has posed a serious problem in recent years owing to the leadcontaining bases or pastes that may be added to herbal 
Table 1. Results of literature review of lead poisoning from traditional Chinese medicine (TCM).

\begin{tabular}{|c|c|c|c|c|c|}
\hline Country & Age(sex) & $\begin{array}{c}\text { Reasons for taking } \\
\text { TCM }\end{array}$ & Medical History & $\begin{array}{c}\text { BLL } \\
\text { (normal range) }\end{array}$ & $\begin{array}{c}\text { Medicine } \\
\text { analysis }^{\mathrm{a}} \\
\text { (lead content) }\end{array}$ \\
\hline $\begin{array}{c}\text { China } \\
\text { (Tsai et al. 2017) }\end{array}$ & $48(\mathrm{M})$ & Difficulty in urinating & $\begin{array}{l}\text { Six herbal pills daily } \\
\text { for } 1 \text { month }\end{array}$ & $\begin{array}{l}62.8 \mu \mathrm{g} / \mathrm{dL} \\
(<40 \mu \mathrm{g} / \mathrm{dL}))\end{array}$ & $90 \mathrm{ppm}$ \\
\hline $\begin{array}{c}\text { China } \\
\text { (Deng et al. 2016) }\end{array}$ & $56(\mathrm{M})$ & Nausea, vomiting, etc. & $\begin{array}{l}\text { Jineijing }^{b}, 500 \\
\text { g/month for } 3 \text { years; } \\
\text { Squama Mantis, } 5 \mathrm{~g} \\
\text { /month for } 3 \text { years }\end{array}$ & $\begin{array}{l}51.7 \mu \mathrm{g} / \mathrm{dL} \\
(<40 \mu \mathrm{g} / \mathrm{dL})\end{array}$ & $3,389 \mathrm{mg} / \mathrm{kg}$ \\
\hline $\begin{array}{c}\text { China } \\
\text { (Ying et al. 2016) }\end{array}$ & $6(\mathrm{M})$ & Epilepsy & $\begin{array}{l}\text { Yuxianwan }^{b} \text {, two pills } \\
\text { daily for } 3 \text { weeks }\end{array}$ & $\begin{array}{l}63.6 \mu \mathrm{g} / \mathrm{dL} \\
(<10 \mu \mathrm{g} / \mathrm{dL})\end{array}$ & $110,000 \mathrm{mg} / \mathrm{kg}$ \\
\hline $\begin{array}{c}\text { China } \\
\text { (Wu et al. 2013) }\end{array}$ & $75(\mathrm{M})$ & $\begin{array}{l}\text { Chronic wound } \\
\text { caused by peripheral } \\
\text { occlusive disease }\end{array}$ & $\begin{array}{l}\text { Herbal patch applied } \\
\text { to wound for } 1 \text { month }\end{array}$ & $\begin{array}{l}226 \mu \mathrm{g} / \mathrm{dL} \\
(<10 \mu \mathrm{g} / \mathrm{dL})\end{array}$ & $517,000 \mathrm{mg} / \mathrm{kg}$ \\
\hline $\begin{array}{c}\text { China } \\
\text { (Lin et al. 2012) }\end{array}$ & $25(\mathrm{M})$ & Health-maintaining & $\begin{array}{l}\text { Qushangjieyusan }{ }^{b} \text { for } \\
3 \text { months }\end{array}$ & $\begin{array}{l}75.5 \mu \mathrm{g} / \mathrm{dL} \\
(<35 \mu \mathrm{g} / \mathrm{dL})\end{array}$ & $80,309.95 \mathrm{mg} / \mathrm{kg}$ \\
\hline $\begin{array}{c}\text { USA } \\
\text { (Parkash et al. 2009) }\end{array}$ & $60(\mathrm{M})$ & $\begin{array}{l}\text { To improve kidney } \\
\text { health }\end{array}$ & $\begin{array}{l}\text { Ayurvedic }{ }^{b} \text { herbal } \\
\text { product for } 2 \text { months }\end{array}$ & $\begin{array}{l}1.89 \mu \mathrm{mol} / \mathrm{L} \\
(<0.48 \mu \mathrm{mol} / \mathrm{L})\end{array}$ & $49 \mathrm{mg}$ per tablet \\
\hline $\begin{array}{c}\text { Thailand } \\
\text { (Woolf et al. 2008) }\end{array}$ & 1(Infant) & Fever & $\begin{array}{l}\text { Ya Kward Pak daily } \\
\text { for } 7 \text { months }\end{array}$ & $\begin{array}{l}61 \mu \mathrm{g} / \mathrm{dL} \\
(<10 \mu \mathrm{g} / \mathrm{dL})\end{array}$ & $109,000 \mathrm{ppm}$ \\
\hline $\begin{array}{c}\text { China } \\
\text { (Auyeung et al. 2002) }\end{array}$ & $23(F)$ & Acne & $\begin{array}{l}\text { Baoningdan }^{b} \text {, four-six } \\
\text { pills daily for } 2 \\
\text { months }\end{array}$ & $\begin{array}{l}3.03 \mu \mathrm{mol} / \mathrm{L} \\
(<1.21 \mu \mathrm{mol} / \mathrm{L})\end{array}$ & Excess lead \\
\hline \multirow[t]{3}{*}{$\begin{array}{c}\text { USA } \\
\text { (Markowitz et al. } \\
\text { 1994) }\end{array}$} & $35(F)$ & $\begin{array}{l}\text { To excrete toxins } \\
\text { from psychiatric } \\
\text { medication }\end{array}$ & $\begin{array}{l}\text { Baoningdan }^{b} \text {, four } \\
\text { pills daily for } 6 \\
\text { months }\end{array}$ & $\begin{array}{l}5.6 \mu \mathrm{mol} / \mathrm{L} \\
(<1.21 \mu \mathrm{mol} / \mathrm{L})\end{array}$ & Excess lead \\
\hline & $48(F)$ & Common cold & $\begin{array}{l}\text { Baoningdan }^{b} \text {, four } \\
\text { pills daily for } 3 \text { days }\end{array}$ & $\begin{array}{l}6.7 \mu \mathrm{mol} / \mathrm{L} \\
(<1.21 \mu \mathrm{mol} / \mathrm{L})\end{array}$ & Excess lead \\
\hline & $45(\mathrm{M})$ & $\begin{array}{l}\text { Chronic obstructive } \\
\text { pulmonary disease }\end{array}$ & Haigefen $^{b}$ for 5 weeks & $76 \mu \mathrm{g} / \mathrm{dL}(\mathrm{NA})$ & $301 \mathrm{mg} / \mathrm{L}$ \\
\hline $\begin{array}{c}\text { USA } \\
\text { (Lightfoote et al. } \\
1977)\end{array}$ & $59(\mathrm{~F})$ & $\begin{array}{l}\text { Post-traumatic } \\
\text { arthralgias }\end{array}$ & $\begin{array}{l}30 \text { pills daily for } 4 \\
\text { months }\end{array}$ & $\begin{array}{l}90 \mathrm{ng} / \mathrm{dL} \\
(10 \text { to } 60 \mu \mathrm{g} / \mathrm{dL})\end{array}$ & $0.5 \mathrm{mg}$ per pill \\
\hline
\end{tabular}

TCM, Traditional Chinese Medicine; BLL, blood lead level; M, Male; F, Female; ppm, parts per million; NA, not avail-

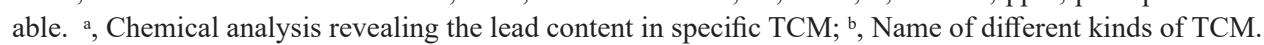

medicines. There are two main sources of TCM-related lead poisoning: mineral drugs (e.g., cinnabaria, sulphur, and realgar) and contaminated herbal medicine (e.g., microorganisms, microbial toxins, and pesticides) (Auyeung et al. 2002). In addition, herbal medicines may be adulterated with unidentified ingredients. In just Taiwan and Hong Kong, $23.7 \%$ and $2.6 \%$, respectively, of herbal medicines may be illegally adulterated with undeclared pharmaceutical products such as heavy metals (Huang et al. 1997; Lanzarotta et al. 2012). We strongly suspect that the homemade TCM medicine taken by the patients in this report had been adulterated with lead.

The biochemical mechanisms of lead toxicity and associated symptoms have been widely investigated. Toxicity may affect cell membranes by interfering with various transport and energy systems, which may shorten erythrocyte survival time and cause hemolysis. In addition, high lead levels can affect the heme synthesis pathway, resulting in the production of free erythrocyte protoporphyrins and eventual anemia (Somashekaraiah et al. 1990; Verheij et al. 2009; Čabarkapa et al. 2015; Alves et al. 2016). Moreover, lead toxicity can cause degeneration of ribosomal ribonucleic acid in erythrocytes, which can lead to the appearance of basophilic stippling on a peripheral smear (Kempe et al. 2005). Decreased preganglionic acetylcholine release and intestinal $\mathrm{Na} / \mathrm{K}$-ATPase inhibition can lead to water flux abnormalities, abdominal colic, and constipation. Axonal degeneration of motor nerves can be associated with extensor weakness or "wrist/ankle drop" (Shobha et al. 2009; Thomson and Parry 2006). The reaction between lead and dental plaque can result in a bluish pigmentation at the gum tooth line, which is known as a 
"lead line." The reaction between lead and other proteins may result in severe adverse effects on multiple organ systems. Myalgia and bone pain may manifest in the early stage, but as these are nonspecific, diagnosis can be difficult without a detailed drug history.

Lead toxic effects are associated with blood lead levels. The effects on our patient were limited to anemia, lead colic, and constipation, probably because his blood lead level was only moderately elevated. Some studies suggest that the rarity of lead encephalopathy in adults is because mature cerebral and cerebellar neurons can sequester lead away from its mitochondrial site of action. This would explain why our patient had no noticeable neurological symptoms. The gastrointestinal symptoms observed in our case are frequently seen. Although abdominal pain is common, critical toxic dilatation of the colon that mimics bowel obstruction is rare. However, there are exceptions in the literature (Begovic et al. 2008). Lead poisoning can be misdiagnosed as nonspecific abdominal pain or acute porphyria. There are two reported cases of misdiagnosis of lead poisoning as porphyria (Markowitz et al. 1994; Tsai et al. 2017). Both porphyria and lead poisoning can impair the heme synthetic pathway, leading to potentially limited heme production. However, acute porphyria (characterized by a potent, variable, catalytic defect of enzymes involved in the heme pathway) is accompanied by overproduction of heme-precursor molecules, specifically delta-aminolevulinic acid (delta-ALA) and porphobilinogen (Marsden 2003; Martin et al. 2004; Begovic et al. 2008; Venkatesh 2013). In lead poisoning, the metal directly inhibits ALA dehydratase activity which catalyzes the second step of heme synthesis in mammals, causing overproduction of aminolevulinic acid with normal porphobilinogen levels (Furuyama et al. 2007; Yang et al. 2012; Bissell et al. 2015). Testing for heme precursors such as delta-ALA and porphobilinogen in urine is the key to the differential diagnosis between lead poisoning and acute porphyria (Akshatha et al. 2014).

Removing exposure to the source of lead is the first step after initiating therapy. This is usually effective for asymptomatic patients with a blood lead level less than 700 $\mu \mathrm{g} / \mathrm{L}(3.38 \mu \mathrm{mol} / \mathrm{L})$. For patients who are symptomatic or have a blood lead level of $700 \mu \mathrm{g} / \mathrm{L}$ or more, chelation treatment is strongly recommended (van Eijkeren et al. 2017). Despite a blood lead level of less than $700 \mu \mathrm{g} / \mathrm{L}$, the symptomatic presentation of our patient prompted chelation therapy. However, prevention of sustained lead exposure was adequate for his wife, who was asymptomatic and had only a slightly elevated blood lead level.

In conclusion, lead poisoning caused by use of uncertified TCM has been frequently reported in recent years. We are concerned that many patients have been affected by this, but have not been properly diagnosed and treated. The symptoms of lead poisoning can be atypical, which makes misdiagnosis easy, and clinicians need to be aware of potential lead exposure when treating patients with a history of TCM usage. The public needs more appropriate informa- tion and more guidance about the use of traditional herbal medicine. The government should speed up legislation to improve the TCM regulatory framework, especially as applied to small, private, and uncertified clinics.

\section{Acknowledgments}

Contributors: We appreciate the helpful suggestions of Xinggang Liu (Ph.D. in Epidemiology, University of Maryland, USA).

We thank Diane Williams, Ph.D., from Liwen Bianji, Edanz Group China (www.liwenbianji.cn/ac), for editing the English text of a draft of this manuscript.

\section{Conflict of Interest}

The authors declare no conflict of interest.

\section{References}

Akshatha, L.N., Rukmini, M.S., Shenoy, M.T., Sadashiva, R.P. \& Prashanth, B. (2014) Lead Poisoning Mimicking Acute Porphyria! J. Clin. Diagn. Res., 8, CD01-CD02.

Alves, J.S., da Silva, F.R., da Silva, G.F., Salvador, M., Kvitko, K., Rohr, P., dos Santos, C.E., Dias, J.F., Henriques, J.A. \& da Silva, J. (2016) Investigation of potential biomarkers for the early diagnosis of cellular stability after the exposure of agricultural workers to pesticides. An. Acad. Bras. Cienc., 88, 349-360.

Auyeung, T.W., Chang, K.K., To, C.H., Mak, A. \& Szeto, M.L. (2002) Three patients with lead poisoning following use of a Chinese herbal pill. Hong Kong Med. J., 8, 60-62.

Begovic, V., Nozic, D., Kupresanin, S. \& Tarabar, D. (2008) Extreme gastric dilation caused by chronic lead poisoning: a case report. World J. Gastroenterol., 14, 2599-2601.

Bissell, D.M., Lai, J.C., Meister, R.K. \& Blanc, P.D. (2015) Role of delta-aminolevulinic acid in the symptoms of acute porphyria. Am. J. Med., 128, 313-317.

Čabarkapa, A., Borozan, S., Živković, L., Milanović-Čabarkapa, M., Stojanović, S., Bajić, V. \& Spremo-Potparević, B. (2015) Implications of oxidative stress in occupational exposure to lead on a cellular level. Toxicol. Environ. Chem., 97, 799-813.

Deng, K., Hu, R. \& Zhang, Y. (2016) An Unusual Cause of Recurrent Severe Abdominal Colic. Gastroenterology, 151, 819-821.

Efferth, T. \& Kaina, B. (2011) Toxicities by herbal medicines with emphasis to traditional Chinese medicine. Curr. Drug Metab., 12, 989-996.

Furuyama, K., Kaneko, K. \& Vargas, P.D. (2007) Heme as a magnificent molecule with multiple missions: heme determines its own fate and governs cellular homeostasis. Tohoku J. Exp. Med., 213, 1-16.

Gupta, N., Goswami, B., Singh, N., Koner, B.C. \& Garg, R. (2011) Lead poisoning associated with Ayurvedic drug presenting as intestinal obstruction: a case report. Clin. Chim. Acta, 412, 213-214.

Huang, W.F., Wen, K.C. \& Hsiao, M.L. (1997) Adulteration by synthetic therapeutic substances of traditional Chinese medicines in Taiwan. J. Clin. Pharmacol., 37, 344-350.

Kempe, D.S., Lang, P.A., Eisele, K., Klarl, B.A., Wieder, T., Huber, S.M., Duranton, C. \& Lang, F. (2005) Stimulation of erythrocyte phosphatidylserine exposure by lead ions. Am. J. Physiol. Cell Physiol., 288, C396-402.

Lanzarotta, A., Crowe, J.B., Witkowski, M. \& Gamble, B.M. (2012) A multidisciplinary approach for the analysis of an adulterated dietary supplement where the active pharmaceutical ingredient was embedded in the capsule shell. J. Pharm. Biomed. Anal., 67-68, 22-27.

Lightfoote, J., Blair, H.J. \& Cohen, J.R. (1977) Lead intoxication 
in an adult caused by Chinese herbal medication. JAMA, 238, 1539.

Lin, G.Z., Wu, F., Yan, C.H., Li, K. \& Liu, X.Y. (2012) Childhood lead poisoning associated with traditional Chinese medicine: a case report and the subsequent lead source inquiry. Clin. Chim. Acta, 413, 1156-1159.

Markowitz, S.B., Nunez, C.M., Klitzman, S., Munshi, A.A., Kim, W.S., Eisinger, J. \& Landrigan, P.J. (1994) Lead poisoning due to hai ge fen. The porphyrin content of individual erythrocytes. JAMA, 271, 932-934.

Marsden, P.A. (2003) Increased body lead burden: cause or consequence of chronic renal insufficiency? N. Engl. J. Med., 348, 345-347.

Martin, C.J., Werntz, C.L. 3rd \& Ducatman, A.M. (2004) The interpretation of zinc protoporphyrin changes in lead intoxication: a case report and review of the literature. Occup. Med. (Lond), 54, 587-591.

Prakash, S., Hernandez, G.T., Dujaili, I. \& Bhalla, V. (2009) Lead poisoning from an Ayurvedic herbal medicine in a patient with chronic kidney disease. Nature Rev. Nephrol., 5, 297-300.

Shaw, D. (2010) Toxicological risks of Chinese herbs. Planta Med., 76, 2012-2018.

Shobha, N., Taly, A.B., Sinha, S. \& Venkatesh, T. (2009) Radial neuropathy due to occupational lead exposure: phenotypic and electrophysiological characteristics of five patients. Ann. Indian Acad. Neurol., 12, 111-115.

Somashekaraiah, B.V., Venkaiah, B. \& Prasad, A.R. (1990) Biochemical diagnosis of occupational exposure to lead toxicity. Bull. Environ. Contam .Toxicol., 44, 268-275.

Thomson, R.M. \& Parry, G.J. (2006) Neuropathies associated with excessive exposure to lead. Muscle Nerve, 33, 732-741.
Tsai, M.T., Huang, S.Y. \& Cheng, S.Y. (2017) Lead poisoning can be easily misdiagnosed as acute porphyria and nonspecific abdominal pain. Case Rep. Emerg. Med., 2017, 9050713. doi:10.1155/2017/9050713, [Epub ahead of print].

van Eijkeren, J.C., Olie, J.D., Bradberry, S.M., Vale, J.A., de Vries, I., Clewell, H.J. 3rd, Meulenbelt, J. \& Hunault, C.C. (2017) Modeling the effect of succimer (DMSA; dimercaptosuccinic acid) chelation therapy in patients poisoned by lead. Clin. Toxicol.(Phila), 55, 133-141

Venkatesh, T. (2013) Editorial role of a clinical biochemist in evaluating the impact of lead poisoning. Indian J. Clin. Biochem., 28, 1-2.

Verheij, J., Voortman, J., van Nieuwkerk, C.M., Jarbandhan, S.V., Mulder, C.J. \& Bloemena, E. (2009) Hepatic morphopathologic findings of lead poisoning in a drug addict: a case report. J. Gastrointestin. Liver Dis., 18, 225-227.

Woolf, A.D., Hussain, J., Mccullough, L., Petranovic, M. \& Chomchai, C. (2008) Infantile lead poisoning from an Asian tongue powder: a case report \& subsequent public health inquiry. Clin. Toxicol.(Phila), 46, 841-844.

Wu, M.L., Deng, J.F., Lin, K.P. \& Tsai, W.J. (2013) Lead, mercury, and arsenic poisoning due to topical use of traditional Chinese medicines. Am. J. Med., 126, 451-454.

Yang, Y., Wu, J. \& Sun, P. (2012) Effects of delta-aminolevulinic acid dehydratase polymorphisms on susceptibility to lead in Han subjects from southwestern China. Int. J. Environ. Res. Public Health, 9, 2326-2338.

Ying, X.L., Xu, J., Markowitz, M. \& Yan, C.H. (2016) Pediatric lead poisoning from folk prescription for treating epilepsy. Clin. Chim. Acta, 461, 130-134. 